\title{
Muğla İlinde 1960-2018 Dönemi Kuraklık Analizi
}

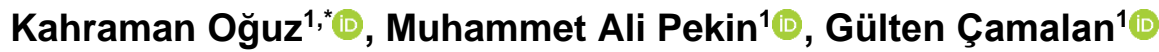

${ }^{1}$ Meteoroloji Genel Müdürlüğü, Araştırma Dairesi Başkanlığı, Ankara.

\section{Özet}

Bu çalıșmanın amacı, Muğla ilinin 1960-2018 periyodundaki yağlș eğilimini ve meteorolojik, tarımsal ve hidrolojik kuraklık durumunu incelemektir. Çalışmada, Meteoroloji Genel Müdürlüğ̈̈'nden elde edilen Muğla Meteoroloji İstasyonu'na ait 1960-2018 dönemi ayllk toplam yağış verileri kullanılmıştır. Yağış verilerine Run (Swed-Eisenhart) homojenlik testi, Mann-Kendall metodu ve Standart Yağış Indeksi yöntemi uygulanmıştır. Ayrıca, yaşanan kuraklıkların şiddet ve süresi de incelenmiştir. Sonuç olarak, Muğla ilinin uzun yıllar yağış ve kuraklık eğilimleri ortaya konulmuştur. Muğla ili için yıllık toplam yağışların 1960-2018 dönemi ortalaması $1180.2 \mathrm{~mm}$ olarak bulunmuştur. Çalışma döneminde en düşük yağış miktarı 2008 yılında $564.6 \mathrm{~mm}$, en yüksek yağış miktarı ise 1969 yllında $1805 \mathrm{~mm}$ olarak görülmüşü̈r. Muğla ilinde hafif nemli ve hafif kurak ay sayıları diğer sınıflara göre daha fazla gerçekleşmiştir. Ayrıca, ekstrem kurak dönem, ekstrem nemli döneme göre daha fazla gerçekleşmiştir. Muğla ilinde nemli ve kurak ay sayılarının, çoğunlukla hafif nemli, orta nemli, hafif kurak ve orta kurak şiddet sınıflarında kümelendiği görülmüştür. Ayrıca analizler, zaman periyodu arttıkça, kuraklı̆̆ın daha az tekrar ettiği ama daha uzun süreli etkili olduğunu göstermektedir. Muğla istasyonunun ölçekler bazında toplam kuraklık siddeti ve toplam kuraklık süreleri hemen hemen benzer ylllara denk gelmistir. Ancak, 3 aylık Standart Yağls Indeksi periyodunda en güçlü toplam kuraklı şiddetinin -13.90 değeri ile 2006 Aralık - 2007 Eylül arasında görülmesine karşllık, yaşanan uzun süreli (12 ay) kuraklı̆̆ın 2000 Haziran - 2001 Mayıs arasında olduğu görülmüștür.

\section{Anahtar Sözcükler}

Kuraklık Analizi, SPI Yöntemi, Kuraklık Şiddet ve Süresi, Muğla

\section{Drought Analysis of Muğla City for 1960-2018 Period}

\begin{abstract}
The objective of this study is to investigate the meteorological, agricultural and hydrological drought of Muğla city for the period of 1960-2018 as well as to analyse precipitation trend. Monthly total precipitation data for the period of 1960-2018 belonging to Muğla meteorological station obtained from the Turkish State Meteorological Service were used in this study. Run (Swed-Eisenhart) homogeneity test, Mann-Kendall method and Standardized Precipitation Index method were applied to precipitation data. In addition, the severity and duration of droughts were examined. As a result, long years' precipitation and drought trend were demonstrated for Muğla city. The annual total precipitation for Muğla city in the period 1960-2018 was found to be $1180.2 \mathrm{~mm}$. The lowest amount of precipitation in the study period was $564.6 \mathrm{~mm}$ in 2008 and the highest amount of rainfall was $1805 \mathrm{~mm}$ in 1969. In the province of Muğla, the number of the humid months was slightly higher than the other classes. In the province of Muğla, the numbers of the mildly humid and moderately dry months were slightly higher than the other classes. It was seen that the numbers of humid and dry months in Muğla province were mostly clustered in mildly humid, moderately humid, mildly dry and moderately dry classes. In addition, analyzes show that drought is less repetitive as the time period increases, but has a longer duration effect. Total drought severity and total drought duration of Muğla station on scales basis coincided with almost similar years. However, in the 3-monthly Standardized Precipitation Index period, the strongest total drought intensity (-13.90) was observed between 2006 December - 2007 September, whereas the long-term (12 months) drought occurred between 2000 June - 2001 May.
\end{abstract}

$\underline{\text { Keywords }}$

Drought Analysis, SPI Methodology, Drought Severity and Duration, Muğla

\section{Giriş}

İklim değişikliği, günümüzün en önemli çevresel problemlerinden birisidir. 20. yüzyılın başından bu yana, sanayi öncesi döneme göre önemli derecede antropojenik sera gazı konsantrasyon artışları gözlemlenmiş ve ortalama olarak $0.9^{\circ} \mathrm{C}^{\prime}$ lik küresel ortalama sıcaklıklarda bir artış tespit edilmiştir (IPCC 2014). Bunun sonucu olarak, karasal ekosistemler çevre olaylarına karşı daha savunmasız hale gelmiş ve sel, 1sı dalgaları, orman yangınları ve kuraklıklarda bir artış gerçekleşmiştir (Estrela ve Vargas 2010; Kreibich vd. 2017). Özellikle Hükümetler arası İklim Değişikliği Paneli (IPCC) bu yüzyılda kuraklıkların, özellikle Akdeniz havzası gibi iklim değişikliğine hassas bölgelerde yoğunlaşabileceği konusunda uyarı yapmıştır (IPCC 2014).

\footnotetext{
* Sorumlu Yazar: Tel: +90 (312) 3022493 Faks: +90 (312) 3022493

Gönderim Tarihi / Received : 28/07/2020

E-posta: koguz@mgm.gov.tr (Oğuz K), mapekin@mgm.gov.tr (Pekin M.A),

Kabul Tarihi / Accepted

: $31 / 08 / 2020$ gcamalan@mgm.gov.tr (Camalan G)
} 
Bu bağlamda, iklim değişikliğinin doğal sonucu olarak karşımıza çıkan kuraklık olaylarının analizi önem arz etmektedir. Nitekim, son yıllarda Türkiye dahil dünyanın pek çok çeşitli bölgeleri için kuraklık olayları çalışılmış ve analiz edilmiştir (Caloiero vd. 2018).

Türkiye'de çeşitli bölgeler için Standart Yağış İndeksi (SPI) yöntemi ile kuraklık analizleri çalışılmıştır. SPI yöntemi kısaca, yağışa bağlı nemlilik ya da kuraklık durumunu belirlemek için kullanılmaktadır. Yetmen (2013), Van gölü havzasının kuraklık durumunu SPI yöntemi ile çalışmıştır. 1-, 3- ve 12- aylık SPI serilerinden havzada kuraklık olasılığının \%45 olduğu, belirli yıllarda ise olağanüstü kurak koşulların gerçekleştiği sonucuna ulaşmıştır. Hınıs (2013), Aksaray için kuraklık durumunu hem normalleştirilmiş yağış indeksi, hem de bütünleşik kuraklık indeksi ile çalışmıştır. Çalışmada, normalleştirilmiş yağış indeksi için 1950-2008 yılları arasındaki yağış verileri kullanmıştır. 2000-2008 yı1ları arasında kuraklık göstergelerinde artma eğilimi olduğunu, orta derece kuraklıklarda ise diğer zamanlara göre 2,5 kat daha fazla artma olduğunu görmüştür. Dinç vd. (2016), SPI yöntemi ile Antalya ilinin kuraklık durumunu incelemiştir. Uzun süreli yağış verilerini kullanarak 3-, 6-, 12- ve 24- aylık SPI değerlerini hesaplamışlardır. Neticede, SPI değerlerinde bir azalma olmadığı, diğer bir deyişle değerlerin normale yakın olduğu, ancak Antalya bölgesinde orta şiddetin üzerinde bir kuraklık durumunun her zaman olabileceği sonucuna ulaşmıştır. Arslan (2017), çalışmasında SPI yöntemini ve MannKendall testini kullanarak Niğde ilinin 1-, 3-, 6-, 9-, 12-, 24- ve 36-aylık kuraklık durumunu analiz etmiştir. Niğde ilinde SPI değerlerinin bir nemlilik eğiliminde olduğu sonucuna ulaşmıştır. Çelik vd. (2018), Doğu Anadolu Bölgesi’nin mevsimlik kuraklık analizini çalışmıştır. 1967-2017 tarihlerini kapsayan dönemde bölgedeki çeşitli illerin kuraklık eğilimini analiz etmek amacıyla SPI yönteminden yararlanmıştır. Sonuçta, bazı illerde nemlilik eğilimi gözlemlerken, bazılarında ise ciddi kuraklık eğilimleri gözlemlemiştir. Bunun yanında, kış mevsiminin de kurak geçebileceğini göstermiştir. Dikici (2019), Asi havzasının kuraklık durumunu çalışmıştır. Kuraklık eğiliminin olup olmadığını tespit etmek amacıyla meteoroloji ve akım gözlem istasyon verilerini kullanmıştır. Çalıştığı bölgede bir kuraklık trendinin olduğu, ancak bunun yavaş seyrettiği sonucuna ulaşmıştır. Ayrıca Pamuk vd. (2004), Ege bölgesinin kuraklık durumunu SPI yöntemi ile çalışmıştır. Elde ettikleri sonuçta, yaz mevsimi dahil olmak üzere Ege bölgesinde kuraklık sınırında bir bulguya rastlamamıştır. Çalışmada ele aldığımız yer olan Muğla ilinin kuraklık analizi daha önce Türkeş ve Altan (2013) tarafından çalışılmıştır. Yazarlar çalışmalarında, Muğla Meteoroloji İstasyonuna ait 1928-2010 dönemi verilerini kullanmıştır. Normalleştirilmiş Yağış İndisi ve bunun yanında Kuraklık İndisi yöntemleri ile gözlenen kuraklıkları ve nemli yılları değerlendirmiştir. Sonuçta, Muğla ilinde en kurak yıllar 1934 ve 2008 y1lları, en nemli dönem ise 1937-1940 olarak bulunmuştur. Ayrıca, 1972, 1990, 1992 ve 2008 yılları şiddetli kurak, 1962, 1969, 1979 ve 1981 yılları çok nemli ve aşırı nemli olarak bulunmuştur.

Yapılan çalışmaların çoğunluğu SPI metoduna dayanmaktadır. Tüm dünyada yaygın bir şekilde kullanılan bu metot, olasılık kavramına dayanmaktadır (McKee vd. 1995). Yağış anomalileri, kuraklığın ortaya çıkması için hidrolojik döngünün çeşitli bileşenlerini etkileyen, küresel iklimin doğal olarak tekrar eden bir özelliğidir (Efstathiou ve Varotsos 2012). Hesaplanması için yağış miktarını dikkate alan bu indeks, anormal sulak ve kurak dönemlerin bir ifadesidir (Guttman 1999). SPI, yağış ile ortalama arasındaki farkın standart sapmaya bölümü ile hesaplanır (McKee vd. 1993). Bu indeksin standart hale getirilmiş olmasından dolayı, dünya genelinde kuraklık etkisini değerlendirmek için kullanılabilmektedir (Manatsa vd. 2010). SPI, belirli bir lokasyon için seçilen zaman ölçeği için olasılık dağılım fonksiyonunu basitçe tahmin ederek kısa, orta veya uzun vadede olmak üzere, herhangi bir zaman ölçeğinde hesaplanabilmektedir (Almedeij 2014). Kuraklık olayı, devam ettiği süre göz önüne alındığında, önce meteorolojik kuraklık olarak kendini gösterir ve uzun süre devam etmesiyle hidrolojik kuraklığa dönüşür. Meteorolojik kuraklık, uzun zaman içinde (1-3 ay) yağışın normal değerlerin altına (belirgin bir şekilde) düşmesi olarak tanımlanmaktadır. Meteorolojik kuraklığı, nem azlığının derecesi ve uzunluğu belirlemekte ve bölgeden bölgeye farklılıklar göstermektedir. Bir örnekle, kurak peryotların belirlenmesi, yağışın belirli bir değerden az gerçekleşmesi durumuna dayanır. Hidrolojik kuraklık ise, şu faktörlerin etkisi ile ilişkilidir: yeraltı su kaynakları, yüzey suları veya yağışlı dönemler. Meteorolojik kuraklığın uzaması durumunda, öncesinde tarımsal kuraklıktan (6-9 ay), bunun daha da uzaması durumunda hidrolojik kuraklıktan (12-24 ay) söz edilir. Uzun süreli yağış azlığı, yüzey akışı ve toprak nemi gibi hidrolojik sistemin bileşenlerinde olumsuz etkiler yaratmaktadır. Yeraltı suları, nehirler ve göllerin su seviyesinde önemli düşüşe neden olur. Bu durum, özellikle canlı yaşamı için büyük bir tehlike yaratır (Kapluhan 2013; Gürler 2017).

$\mathrm{Bu}$ çalışmanın amacı, Muğla ilinin yağış ve kuraklık durumunu SPI yöntemiyle incelemektir. Bu çalışmada diğer çalışmalara ek olarak, 1-, 3-, 6-, 9-, 12-, 24- ve 36-aylık SPI periyodu için kuralık yüzdesi, şiddeti ve süresi de çalışılmıştır. Çalışmada, Meteoroloji Genel Müdürlüğünden elde edilen Muğla meteoroloji istasyonuna ait 1960-2018 dönemi aylık yağış verileri kullanılmıştır. Bu veriler ile öncelikle Muğla ilinin yıllık toplam yağış dağılımı ve trendi incelenmiştir. Sonrasında, SPI yöntemi kullanılarak Muğla ilinin kuraklık durumu incelenmiş ve kuraklık trendi analiz edilmiştir. Bunun yanında, toplam kuraklık şiddeti ve süresi ile birlikte, 6 ay ve 2 ay dan daha fazla süreli kurak geçen dönemlerin sıklığ da incelenmiştir. 


\section{Materyal ve Metot}

\section{1. Çalışma Alanı}

Çalışma alanı Muğla ilini içermektedir. Muğla ili, coğrafi konumu itibariyle Türkiye'nin güney batısında, $36^{\circ} 17^{\prime}-37^{\circ}$ $33^{\prime}$ kuzey enlemleri ve $27^{\circ} 13^{\prime}$ - 29 $9^{\circ} 46^{\prime}$ doğu boylamları arasında yer almaktadır (Şekil 1). Güneyinde Akdeniz, batısında Ege denizi yer almaktadır. Şehrin büyük çoğunluğu ormanlık alanlarla kaplıdır. Deniz kıyısı itibariyle Türkiye'nin en uzun sahil kenarına sahiptir. Denizden ortalama yüksekliği 650 metredir. Denize olan konumu bölgenin ikliminin şekillenmesinde önemli bir yere sahiptir.

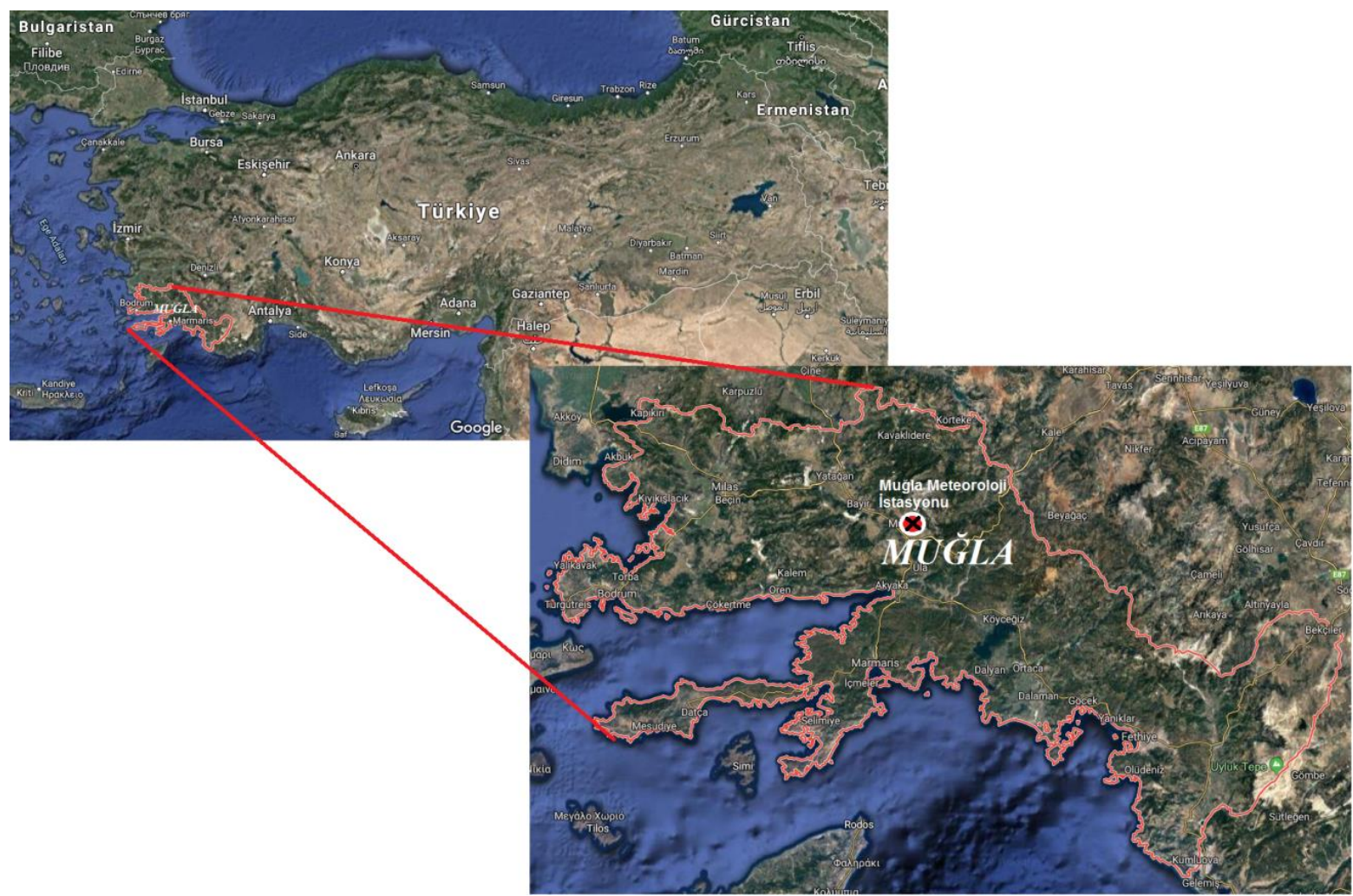

Şekil 1: Muğla ilinin ve meteoroloji istasyonunun konumu

Denizin ve yükseltilerin yanı sıra yer şekillerinin uzanış durumu da ilin ikliminde önemli bir rol oynamaktadır. Fethiye ilçesini Antalya ve Burdur'a bağlayan Karabel geçidi ile Burdur ve Denizli’ye bağlayan Nif geçitlerinin güneyi ile Muğla'yı Marmaris, Köyceğiz, Ortaca, Dalaman ve Fethiye'ye bağlayan Sakar ve Çiçekli Bel geçitlerinin altında Akdeniz iklimi özellikleri bunun dişında ise İl merkezi dahil Ege iklimi özellikleri görülmektedir. İlin iç kesimlerinde ise karasal iklim özelliklerine de rastlanmaktadır (URL-1 2008). Yazları sıcak ve kurak, kışları 1lık ve yağışlı geçmektedir. Yaz kuraklıklarının belirgin olmasının sebebi, yağışların büyük çoğunluğunun kış mevsiminde düşmesi sebebiyledir. Yerel coğrafi koşullara bağlı olarak sıcaklık, nemlilik ve yağış değişiklik göstermektedir. Kıyılardan iç bölgelere doğru gidildikçe sıcaklıklar düşer, karasal iklim hakim olmaya başlar (Özsalmanlı 2014).

Çalışmada verileri kullanılan Muğla meteoroloji istasyonu, $37.2095^{\circ}$ enlem ve $28.3668^{\circ}$ boylam koordinatlarında bulunmaktadır. Denize olan yüksekliği 646 metredir. Muğla meteoroloji istasyonunda rüzgar, sıcaklık, nem, yağış, basınç, güneşlenme ve toprak sıcaklıkları ölçümleri yapılmaktadır. Muğla meteoroloji istasyonu verileri, il sınırları içerisinde uzun süreli ve düzenli ölçüm yapan bir istasyon olması sebebiyle bu çalışmada tercih edilmiştir.

\subsection{Run (Swed-Eisenhart) Homojenlik Testi}

Run (Swed-Eisenhart) testi, verilerin homojenliğini test etmek için kullanılmaktadır. Run testi, analize tabi tutulacak verinin rastgele olup olmadığını, diğer bir deyişle aynı toplumdan gelip gelmediğini analiz eder. Neticede verilerin, birbirinden bağımsız olduğu veya olmadığı durumu şeklinde iki varsayım kontrol edilebilir (Oliver 1981). Analiz edilecek verilerin zaman serisi belirli bir seviyeden kesilip, analizdeki her bir değerin bu seviyenin altında veya üstünde olması durumu belirlenir. Kesilmek amacıyla göz önünde bulundurulabilecek seviye; ortalama değer, orta değer veya en sık değer (mod) olabilir. Bu yolla veriler, orta değerin üstünde veya altında seyreder. Üstünden ve altından birbirine geçiş sayıları toplamı run sayısı olarak adlandırılır. Run testi; 
$Z=\frac{r-\frac{2 N_{A} N_{U}}{N_{A}+N_{U}}+1}{\sqrt{\frac{2 N_{A} N_{U}\left(2 N_{A} N_{U}-N\right.}{N^{2}(N-1)}}}$

şeklinde hesaplanır. Burada Z: test sonucu, N: veri sayısı; r: run (değişim) sayısı, $\mathrm{N}_{\mathrm{A}}$ : orta seviye altında olanlar sayısı; $\mathrm{N}_{U}$ : üstte olan değerler sayısıdır. (1) nolu formülle elde edilen test değeri \pm 1.96 arasında ise verilerin, \% 95 güven aralığında rastgele (homojen) dağıldığı kabul edilir (Toros 1993).

\subsection{Mann-Kendall Metodu}

Muğla ilinin yağış ve kuraklık trendinin analizine yönelik olarak Mann-Kendall Metodu kullanılmıştır. Mann-Kendall pek çok çalışmada yaygın olarak kullanılan bir metottur. Bundaki en önemli etken, metodun bir veri dizisindeki eksik veya hatalı verilerden etkilenmeyen parametrik olmayan bir test olmasıdır. Bu testte gerçek veri yerine, verinin seri içinde bulunan mertebesi (yi) kullanılır. Her bir yi, önceki mertebelerden büyük olanları sayarak ni gibi bir sayı ile tanımlanır ve buna göre test değeri $t$ :

$t=\sum_{i=1}^{n} n_{i}$

olarak hesaplanır. (2) eşitliğinden hesaplanan $t$ test değerinin ortalaması $E(t)$ ve varyansı $\operatorname{var}(t)$ :

$$
\begin{aligned}
& E(t)=\mu=\frac{n(n-1)}{4} \\
& \operatorname{var}(t)=\frac{n(n-1)(2 n+5)}{72}
\end{aligned}
$$

Mann-Kendall test değeri $\mathrm{u}(\mathrm{t})$ ise:

$$
u(t)=(t-E(t)) / \sqrt{\operatorname{var}(t)}
$$

olarak hesaplanır (Sneyers 1990).

u(t)'nin sıfıra yakın değerleri zamanla bir değişimin olmadığı varsayımını, $u(t)$ 'nin büyük değerleri ise bir değişimin olduğu varsayımını ifade eder. Diğer testlerde olduğu gibi (+) zamanla bir artışı, (-) olması ise zamanla bir azalmanın olduğunu gösterir (Toros 1993). Geriye doğru Mann-Kendall test istatistiği u'(t) hesabı da benzer şekilde gerçekleştirilir. Verilerde zamanla anlamlı bir trend olup olmadığı ve trendin yönü, Mann-Kendall test istatistiği u(t) ile belirlemektedir. Grafiksel olarak, u(t) ve u'(t)'nin kesiştikleri ilk nokta, değişimin başladığı yerdir. Bu ikisi daha sonradan birbirlerine yaklaşabilirler veya uzaklaşabilirler. Trendin kuvveti, kesişme olmadan geçen zamanla belirlenir. $u(t)$ ve $u$ ' $(t)$ birbirlerine birçok defa yaklaşarak paralel bir şekilde ilerlerse, bu durum trendin olmadığını ifade eder (Chrysoulakis vd. 2002; Yerdelen 2013).

\subsection{SPI Yöntemi}

Standart Yağış İndeksi (SPI), iklim değişkenliğini değerlendirmek için geliştirilmiş bir yöntemdir (McKee vd. 1993). SPI, öncelikle kuraklığın tanımlanması ve izlenmesi için geliştirilmiş bir yöntemdir. Yöntem, herhangi bir yağış istasyonunda ölçülmüş yağış verileri ile belirli bir zaman ölçeğinde kuraklığın belirlemesini sağlar. Ekstrem nemli dönemleri belirlemek için de kullanılabilir. Amaç, farklı iklime sahip bölgeler arasında karşılaştırılabilir olması amacıyla yağışa tek bir sayısal değer atamaktır (Das vd. 2016). Diğer bir deyişle, SPI yöntemi kuraklık veya nemlilik durumunun tespitine yönelik bir standartlaştırma işlemidir. SPI'ın negatif değerleri kuraklığı ifade ederken, pozitif değerleri ise nemliliği ifade etmektedir. SPI değeri:

$$
\mathrm{SPI}=(\mathrm{Xi}-\mathrm{Xort}) / \sigma
$$

olarak hesaplanır. Burada, Xi ölçülen yağış verisini, Xort yağış ortalamasını ve $\sigma$ ise standart sapmayı ifade etmektedir. Tablo 1'de SPI indeks değerlerine göre kuraklık ve nemlilik sınıfı görülmektedir. 
Tablo 1: Standart yağış indeksi sınıfları (Topçu ve Seçkin 2016'dan uyarlanmıştır)

\begin{tabular}{|c|c|}
\hline SPI Değerleri & Kuraklık Sınıfi \\
\hline 2.00 veya daha fazla & Ekstrem Nemli \\
\hline $1.50-1.99$ & Şiddetli Nemli \\
\hline $1.00-1.49$ & Orta Nemli \\
\hline $0.0-0.99$ & Hafif Nemli \\
\hline $0.0-(-0.99)$ & Hafif Kurak \\
\hline$(-1.00)-(-1.49)$ & Orta Kurak \\
\hline$(-1.50)-(-1.99)$ & Şiddetli Kurak \\
\hline$(-2.00)$ veya daha az & Ekstrem Kurak \\
\hline
\end{tabular}

SPI'ın 1-3 aylık dönemleri için hesaplanan değerleri meteorolojik kuraklığı, 6-9 aylık dönemleri için hesaplanan değerleri tarımsal kuraklığı, 12-24 aylık dönemleri için hesaplanan değerleri hidrolojik kuraklığı ifade etmektedir (Gürler 2017).

\subsection{Kuraklık Şiddet ve Süresi}

Kuraklık, SPI değerleri sıfırın altına düştüğünde tanımlandığından, bir kuraklık olayı, negatif SPI değerlerine sahip bir dönem olarak kabul edilir. Kuraklık olayının süresi, başlangıcı (dahil) ve bitiş ayı (dahil değil) arasındaki ay sayısına eşittir. Kuraklık süresi (D), SPI indis değerlerinin negatif olduğu değerlerden başlayarak art arda 0 (sıfıra)'a eşit ve SPI değerlerinin pozitif olduğu zaman sona erdiği dönem uzunluğudur. Şiddeti ise, SPI çizgisi ile yatay eksen (SPI = 0) arasındaki integral alanın kuraklığın başlangıç ayına kadar olan mutlak değeridir. Kuraklık şiddeti (S), kuraklık süresi içinde kalan indis değerlerinin toplanmasıyla elde edilen kümülatif SPI değerleri olup toplam kuraklık şiddetini verir ve kuraklığın büyüklügüüü ifade eder (Yevjevich 1967; Spinoni vd. 2014). SPI indeks değerine dayalı kuraklık şiddet (S) ve kuraklık süresi (D) grafiği Şekil 2'de gösterilmektedir.

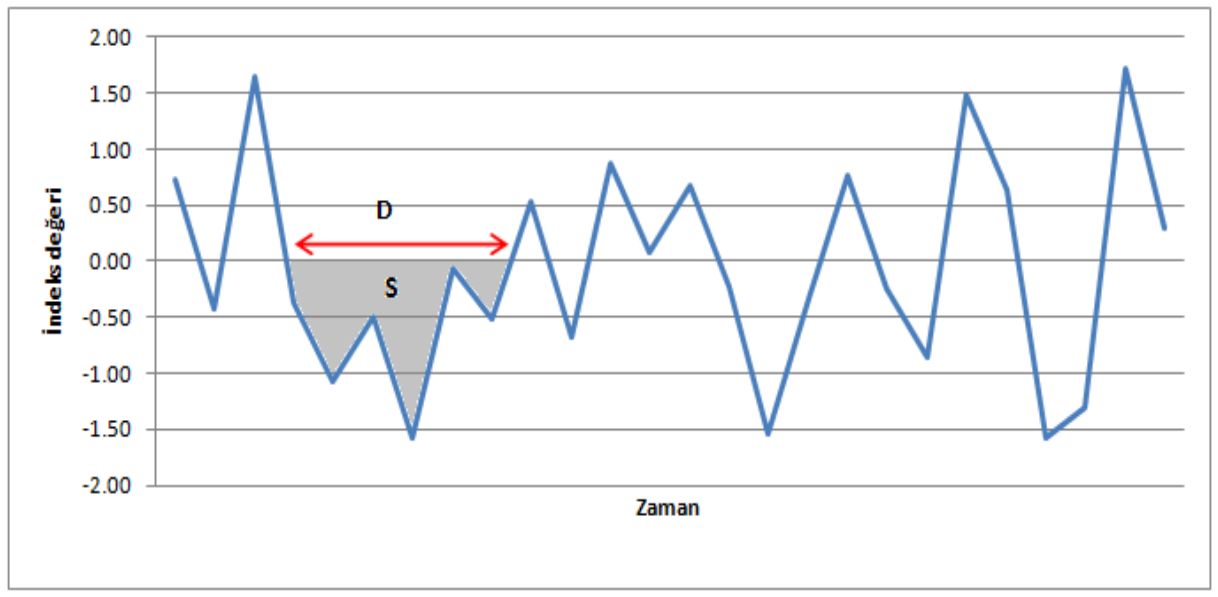

Şekil 2: SPI indeks değerine dayalı kuraklık şiddet ve kuraklık süresi grafiği

İlgili tanımlara ait hesaplamalar:

$\mathrm{S}=-\sum_{\mathrm{i}=1}^{\mathrm{D}} \mathrm{SPI}_{\mathrm{i}}$

$\mathrm{I}=\mathrm{S} / \mathrm{D}$

formülleriyle hesaplanır. Burada S: kuraklık şiddetini, D: kuraklık süresini ifade eder.

Kuraklık süresinin uzunluğunu ve kuraklık şiddetinin büyüklüğünü ölçmek için bir eşik değeri tanımlanmalıdır. Hesaplamalar yapılırken eşik değer olarak, indisin kurak/nemli eşiği olan sıfır değeri kabul edilmiştir. Muğla istasyonu için SPI-3, SPI-6, SPI-12, SPI-24, SPI-36 ve SPI-48 aylık ölçeklerde kuraklık şiddet indis hesapları yapıldıktan sonra, indisin tüm zaman serisi için kurak (indisin sıfırın altında kaldığı) dönemlerin şiddet süre ve yoğunluk değerleri hesaplanmış ve her birinin en ekstrem olduğu olumsuz değerler seçilmiştir. Bu açıklamalar neticesinde, Muğla istasyonun tüm ölçekler bazında indis hesapları yapıldıktan sonra, indisin tüm zaman serisi için kurak (indisin sıfırın altında kaldığı) dönemlerin şiddet ve süre değerleri hesaplanmış ve her birinin en ekstrem olduğu olumsuz değerler seçilmiştir. 


\section{Sonuçlar ve Tartışma}

Analizde kullandığımız yağış ölçümleri, yıllık toplam yağış verilerini içermektedir. Verilerin homojenliğini test etmek amacıyla uygulanan run testinin sonuçları Tablo 2'de verilmektedir. Sonuçlara göre, ortanca değer 1159.4, run (değişim) sayısı 37, orta seviye altında olanların sayısı 30 olarak bulunmuştur. $Z$ değerinin ise \pm 2.23 aralığında olduğu görülmektedir. Bu durumda, yağış verileri zaman serisi \%95 güven aralığında homojen olarak bulunmamıştır. Verilerin homojenliğini bozan çeşitli faktörler bulunmaktadır. Bunlar arasında, ölçüm istasyonunun yerinin değişmesi, istasyon çevresindeki bazı değişiklikler, yanardağ patlaması gibi çeşitli faktörler yer almaktadır (Macana 2014). Veriler, run testine göre \%95 güven aralığında homojen olmasa da, çalışmada kullanılmıştır.

Tablo 2: Run testinin istatistiki sonuçları

\begin{tabular}{|c|c|c|c|c|c|}
\hline Ortanca & $\mathbf{r}$ & $\mathbf{N}$ & $\mathbf{N}_{\mathbf{A}}$ & $\mathbf{N}_{\mathbf{B}}$ & $\mathbf{Z}$ \\
\hline 1159.4 & 37 & 59 & 30 & 29 & 2.23 \\
\hline
\end{tabular}

Y1llık toplam yağışların 1960-2018 dönemi ortalaması 1178.2 mm olarak bulunmuştur. Y1llık toplam en düşük yağıŞ miktarı 2008 yılında 564.6 mm olarak gerçekleşmiştir. Yıllık toplam en yüksek yağış miktarı ise 1969 yılında 1805 mm olarak gerçekleşmiştir. Yıllık toplam yağışların değişimini gösteren grafiğe göre, yağışlarda bir salınımın, diğer bir deyişle bir düzensizliğin olduğu göze çarpmaktadır. Mann-Kendall testine göre ise, yağış serisinde \%95 güven aralığında artış veya azalış trendi yoktur (Şekil 3).

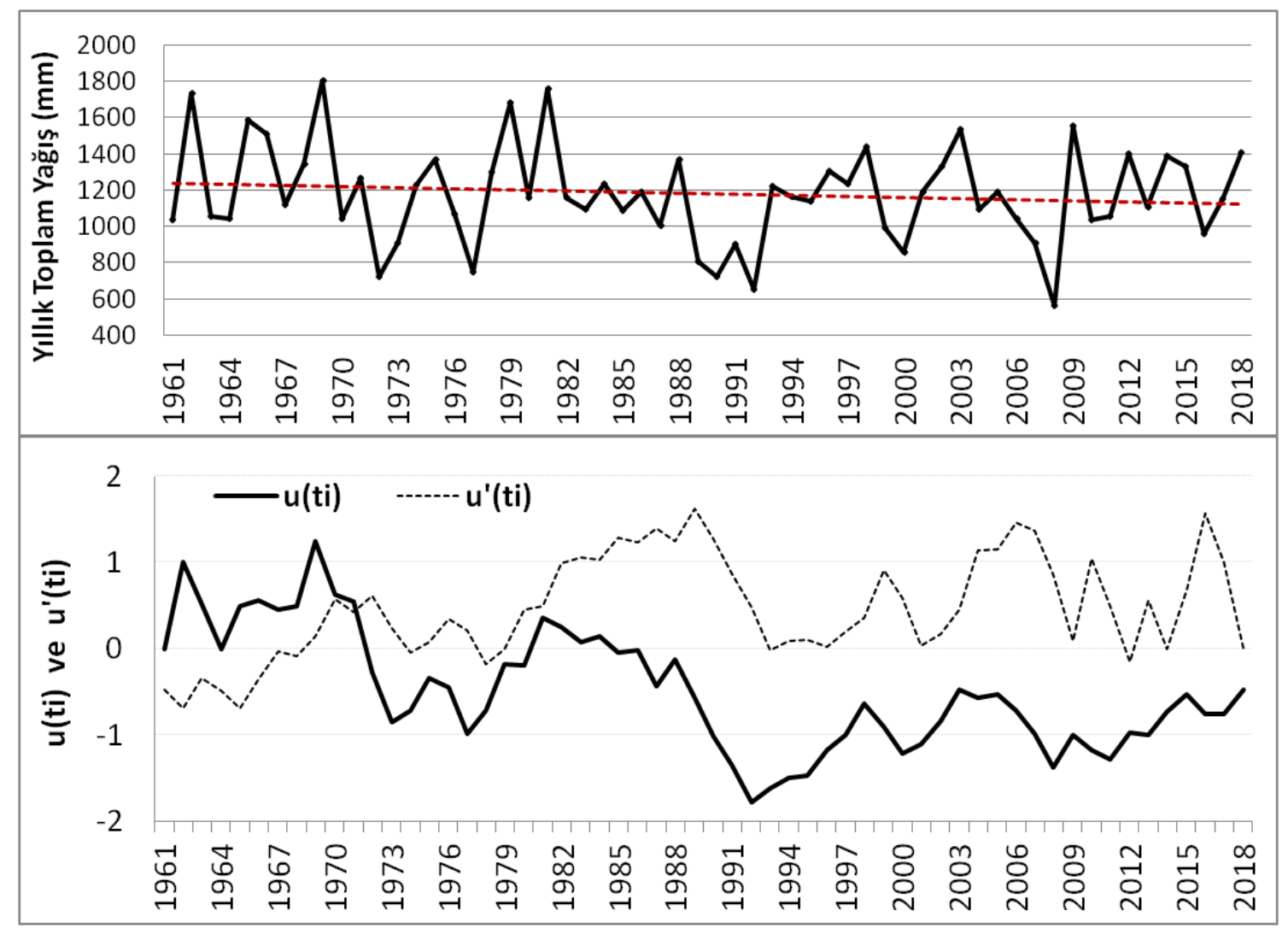

Şekil 3: Muğla ili yılık toplam yağış değişimi (üstte) ve Mann-Kendall trend testi (altta)

Muğla ilinde 1960-2018 döneminde SPI-3, SPI-6, SPI-12, SPI-24, SPI-36 ve SPI-48 indeksi değerlerine göre nemli ve kurak geçen ay sayılarının yüzde dağılım grafiği Şekil 4'de gösterilmektedir. En yüksek yüzde dağılımlar, hafif kurak ve hafif nemli sınıf dağılımında seyretmiştir. Hafif nemli ve hafif kurak dönemde 3 aylık SPI periyodunda toplamda \%67, 6 aylık SPI periyodunda \%64, 12 aylık SPI periyodunda \%62, 24 aylık SPI periyodunda \%64, 36 aylık SPI periyodunda \%61, 48 aylık SPI periyodunda \%64 olarak yüzde dağılım bulunmuştur. Yüzde dağılımlar, hafif nemli ve hafif kurak sınıf aralıklarında ölçekler bazında çoğunlukla \%61-64 arasında seyretmiştir. Orta kurak sınıfta ölçekler bazında \%7-12 arasında, şiddetli kurak sınıfında ölçekler bazında \%4-8 aralığında, ekstrem kurak sınıfta ölçekler bazında ise \%2-4 aralığında olarak bulunmuştur. 


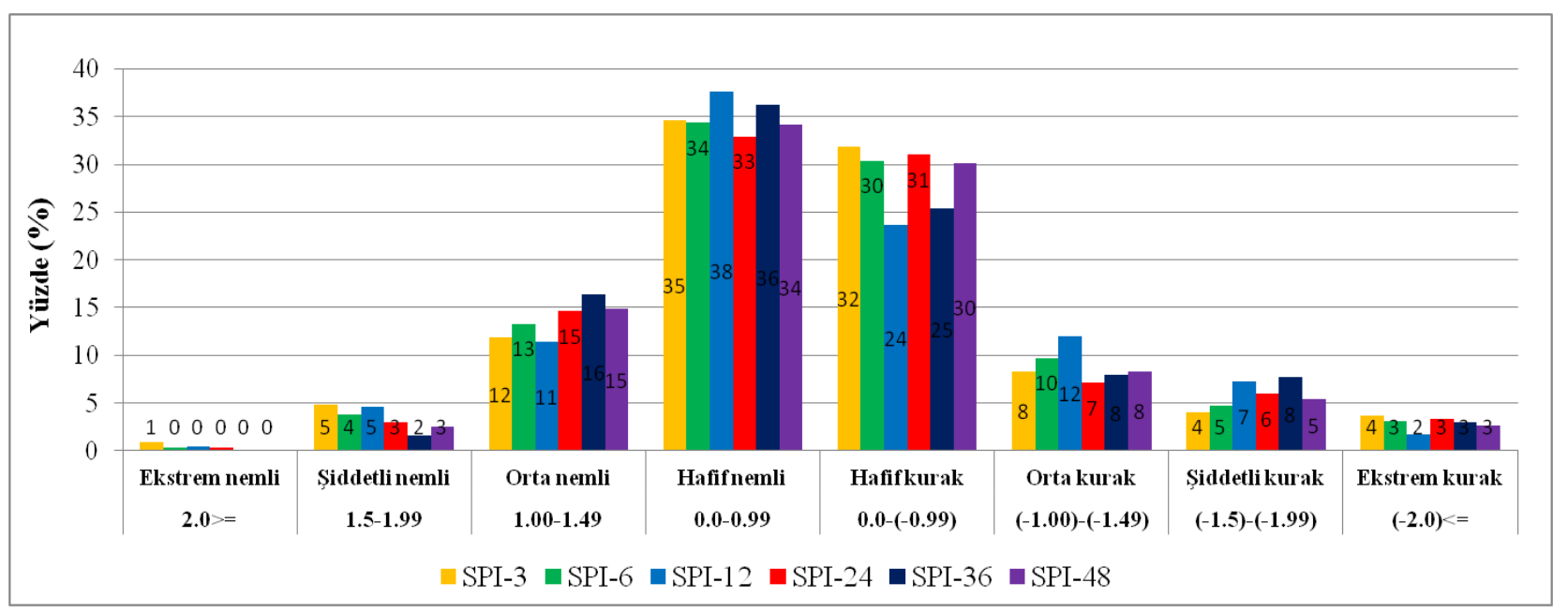

Şekil 4: Muğla ilinde nemli ve kurak geçen ay sayılarının yüzde dağılımları

Muğla ilinin yağış verilerinden elde edilen 3-, 6-, 12-, 24-, 36- ve 48- aylık SPI değerleri ise sırasıyla Şekil 5, 6, 7, 8, 9 ve 10'da verilmiştir. Hesaplama yapılırken tüm SPI periyotlarında tek bir ay baz alınarak değil de her aylarda hesaplama yapılmıştır. Grafiklere göre, tüm SPI periyotlarında bazı dönemlerin kurak, bazı dönemlerin ise nemli geçtiği, yani bir salınımın olduğu görülmektedir. Kuraklık durumunun ani bir şekilde değişiklik gösterebildiği görülmektedir. Ayrıca, grafiklerde belirgin bir eğilimin olmadığı görülmektedir. Meteorolojik kuraklığı ifade eden 3 aylık SPI grafiğine bakıldığında (Şekil 6), ekstrem kurak dönemlerin 1964, 1965, 1968, 1969, 1970, 1973, 1981, 1984, 1989, 1990,1992 , 1999, 2004, 2007, 2008, 2012 ve 2016 y1llarında olduğu, ekstrem nemli dönemlerin ise 1975, 1998, 2002,2015 ve 2018 yıllarında olduğu görülmektedir. 6 aylık SPI için de kuraklık durumu benzer şekilde gerçekleşmiştir (Şekil 6). Diğer bir deyişle, meteorolojik kuraklığın görüldüğü dönemler, tarımsal kuraklıkta da benzer şekilde gerçekleşmiştir. Türkeş ve Altan (2013) tarafından Muğla ili için yapılan çalışmada, 1990, 1992 ve 2008 yılları benzer şekilde şiddetli kurak olarak bulunmuştur. Tarımsal kuraklığı ifade eden diğer bir sınıf olan 9 aylık SPI değerleri (burada gösterilmemiştir), 6 aylık SPI değerlerine benzer şekilde gerçekleşmiştir. Hidrolojik kuraklığı ifade eden 12 aylık SPI grafiğine (Şekil 7) bakıldığında, ekstrem kurak dönemlerin 1990, 1992, 2000, 2001, 2007 ve 2008 yıllarında olduğu, ekstrem nemli dönemlerin ise 1966, 1969 ve 2004 yıllarında olduğu görülmektedir. Daha uzun dönem hidrolojik kuraklığ ifade eden 24 aylık SPI sonuçlarına bakıldığında, ekstrem kurak dönemlerin 1990, 1991, 1992, 1993, 2001 ve 2008 yıllarında olduğu, ekstrem nemli dönemlerin ise yalnızca 2004 yılında olduğu görülmektedir. 36 ve 48 aylık SPI sonuçları da (Şekil 9 ve Şekil 10), 24 aylık SPI sonuçlarına (Şekil 8) benzer şekildedir.

En ekstrem kurak dönemler 3, 6, 12, 24, 36 ve 48 aylık SPI dönemlerinde sirasıyla 2016 yılı Aralık, 1984 Ekim, 2008 Aralık, 2008 Ekim, 1992 Aralık ve yine 1992 Aralık’ta görülmüştür. Bu aylarda SPI değerleri sırasıyla -3.061, -3.301, 2.728, -2.597, -2.821 ve -3.075 olarak hesaplanmıştır. En ekstrem nemli dönemler ise, 3, 6, 12, 24 ve 36 aylık SPI dönemlerinde sırasıyla 1975 Haziran, 1962 Aralık, 2004 Ocak, 2004 Ocak, 1981 Aralık ve yine 1981 Aralık’ta görülmüştür. $\mathrm{Bu}$ aylarda SPI değerleri sırasıyla 2.344, 2.145, 2.115, 2.039, 2.001 olarak hesaplanmıştır. 48 aylık SPI döneminde ekstrem nemli dönem görülmemiştir. En yüksek SPI değeri, şiddetli nemli durumu ifade eden 1.920 olarak hesaplanmıştır (Tablo 3).

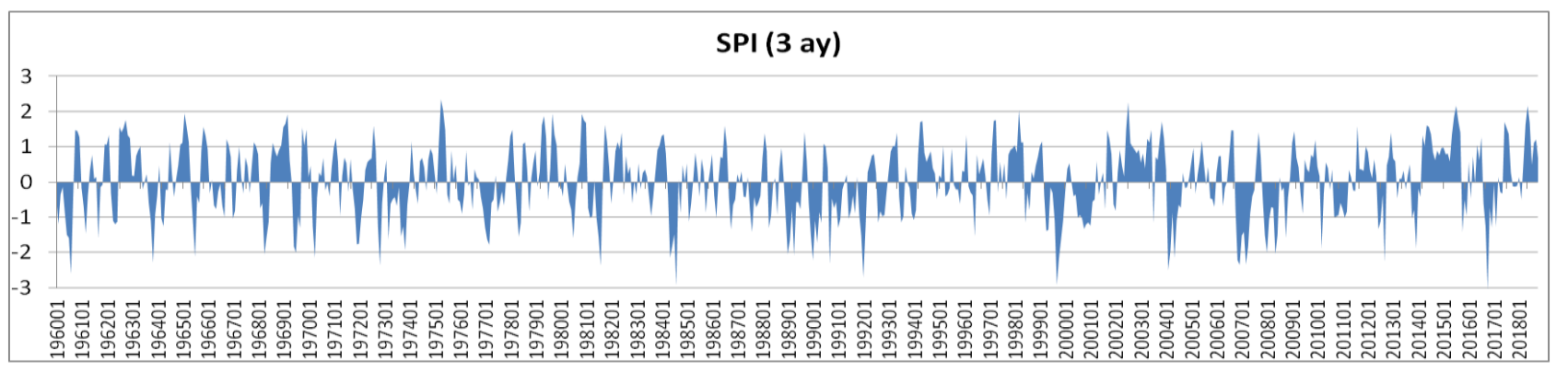

Şekil 5: Muğla ilinin 3 aylık SPI değerleri 


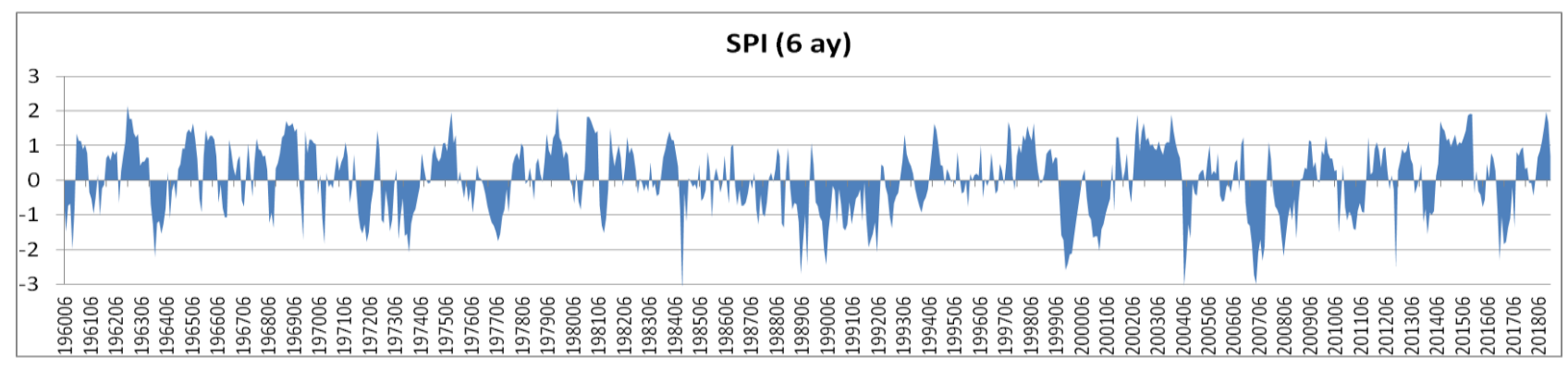

Şekil 6: Muğla ilinin 6 aylık SPI değerleri

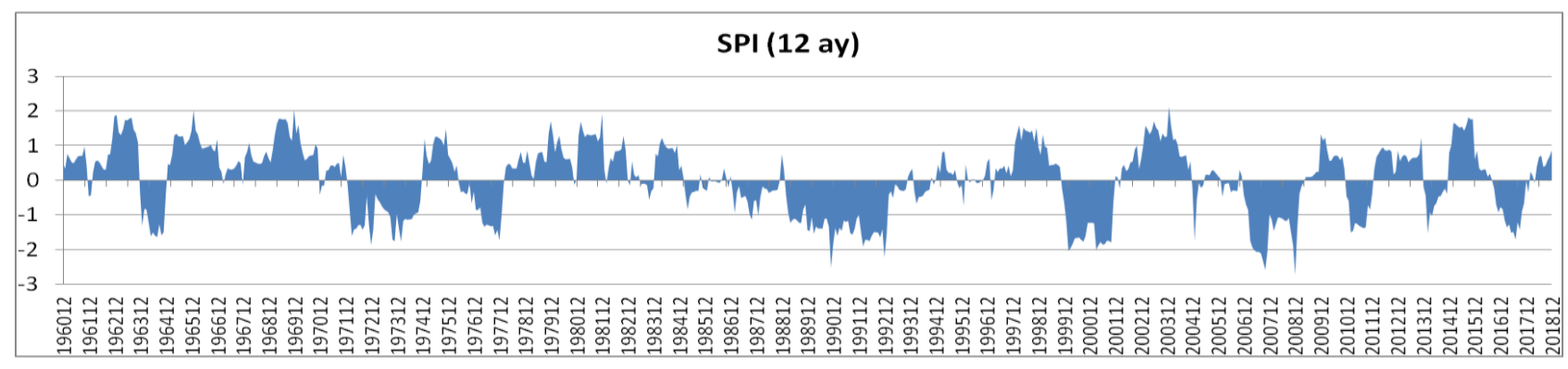

Şekil 7: Muğla ilinin 12 aylık SPI değerleri

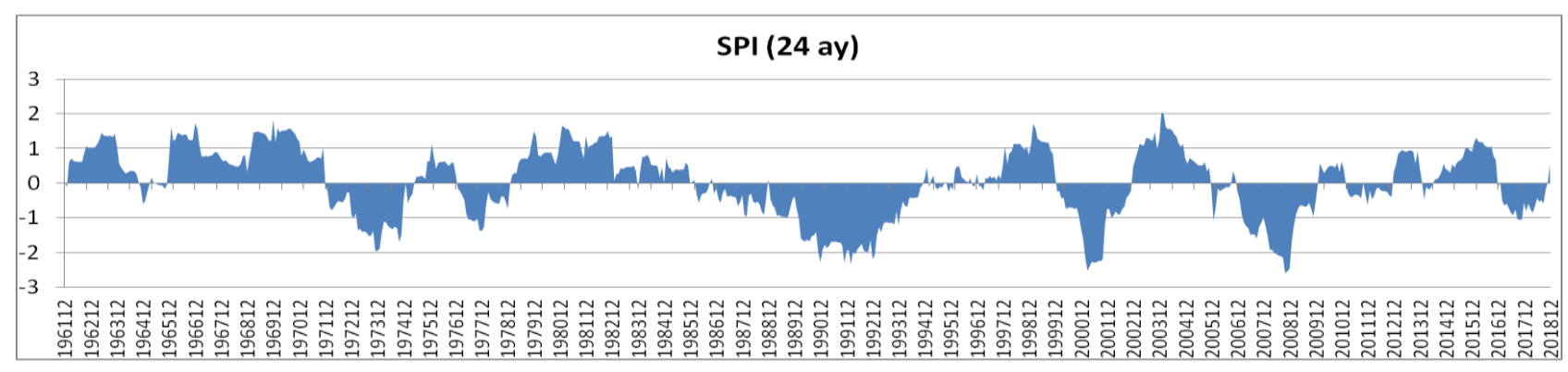

Şekil 8: Muğla ilinin 24 aylık SPI değerleri

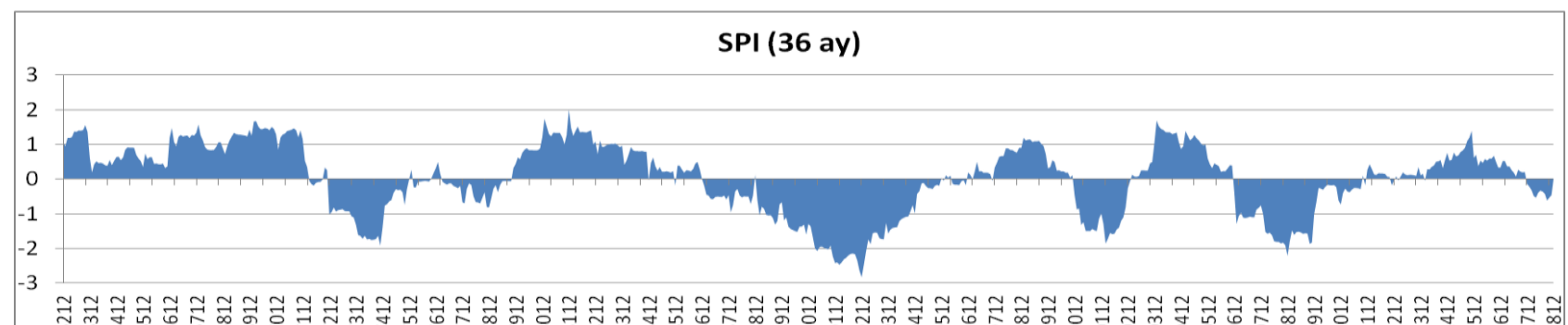

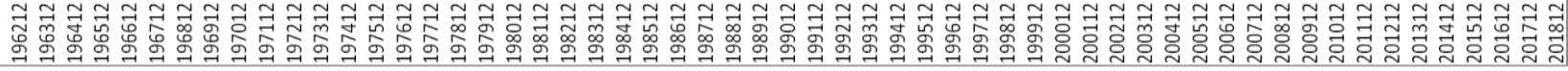

Şekil 9: Muğla ilinin 36 aylık SPI değerleri

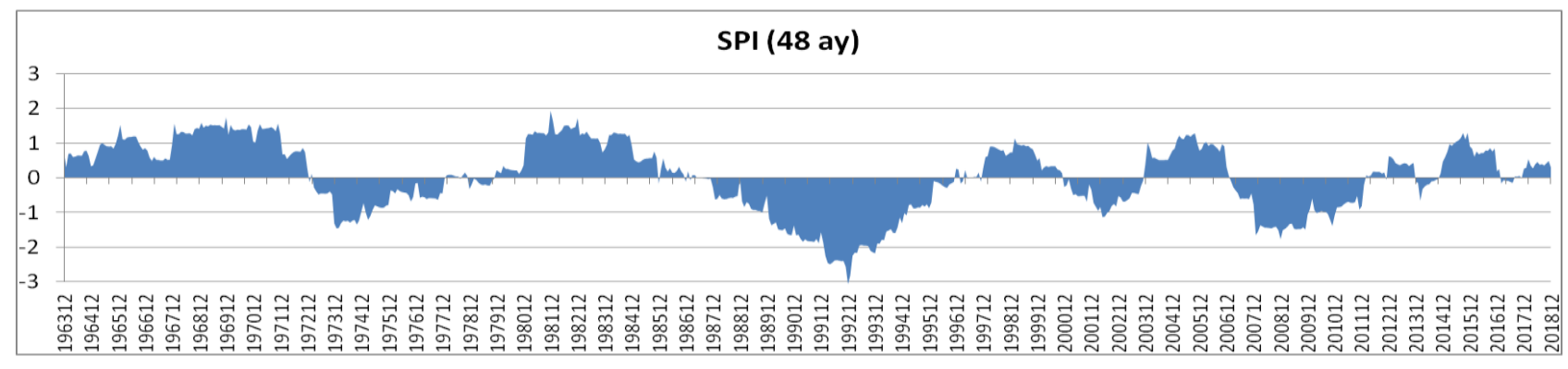


Tablo 3: Minimum ve maksimum SPI değerleri

\begin{tabular}{|c|c|c|c|c|c|c|}
\hline & SPI-3 & SPI-6 & SPI-12 & SPI-24 & SPI-36 & SPI-48 \\
\hline \multirow{2}{*}{ Minimum } & -3.061 & -3.301 & -2.728 & -2.597 & -2.821 & -3.075 \\
\cline { 2 - 7 } & $(2016$ Aralık) & $(1984$ Ekim) & (2008 Aralık) & (2008 Ekim) & (1992 Aralık) & (1992 Aralık) \\
\hline \multirow{2}{*}{ Maksimum } & 2.344 & 2.145 & 2.115 & 2.039 & 2.001 & 1.92 \\
\cline { 2 - 7 } & $(1975$ Haziran) & (1962 Aralık) & (2004 Ocak) & (2004 Ocak) & (1981 Aralık) & (1981 Aralık) \\
\hline
\end{tabular}

Tablo 4'de ise ardışık olarak oluşan en güçlü toplam kuraklık şiddetleri (Total Drought Severity) ve en uzun süren toplam kuraklık süreleri (Total Drought Duration) ile bunların başlama ve bitiş yılları görülmektedir. Burada toplam kuralık şiddeti, kümülatif olarak hesaplanan SPI değerlerinin en büyüğü alınarak elde edilmiştir. Toplam kuraklık süresi ise, göz önüne alınan zaman süresinde her bir kuraklık süresinin toplanması sonucu elde edilmiştir. Muğla istasyonunun ölçekler bazında toplam kuraklık şiddeti ve toplam kuraklık sürelerinin başlama ve bitiş yıllarına baktığımızda hemen hemen benzer yıllara denk geldiğini görürüz. Ancak 3 aylık SPI periyodunda, en güçlü toplam kuraklık şiddeti -13.90 ile 2006/12-2007/09 yılları arasında görülmesine karşılık etki süresi daha düşüktür. Buna karşılık yaşanan en uzun süren kuraklık (12 ay) 2000/06-2001/05 yılları arasında görülmüştür.

Tablo 4: Oluşan kuraklık özelliklerinin başlama ve bitiş yılları

\begin{tabular}{|c|c|c|c|c|c|c|}
\cline { 2 - 7 } \multicolumn{1}{c|}{} & \multicolumn{3}{c|}{ En güçlü } & \multicolumn{3}{c|}{ En uzun } \\
\hline SPI Aralığı & S (Şiddet) & $\begin{array}{c}\text { Başlama } \\
\text { Yıl/Ay }\end{array}$ & $\begin{array}{c}\text { Bitiş } \\
\text { Yıl/Ay }\end{array}$ & D (Süre) & $\begin{array}{c}\text { Başlama } \\
\text { Yıl/Ay }\end{array}$ & $\begin{array}{c}\text { Bitiş } \\
\text { Yıl/Ay }\end{array}$ \\
\hline SPI-3 & -13.9 & $2006 / 12$ & $2007 / 09$ & 12 & $2000 / 06$ & $2001 / 05$ \\
\hline SPI-6 & -32.92 & $1990 / 01$ & $1992 / 07$ & 31 & $1990 / 01$ & $1992 / 07$ \\
\hline SPI-12 & -69.44 & $1989 / 02$ & $1993 / 10$ & 57 & $1989 / 02$ & $1993 / 10$ \\
\hline SPI-24 & -93.47 & $1989 / 01$ & $1994 / 11$ & 71 & $1989 / 01$ & $1994 / 11$ \\
\hline SPI-36 & -116.82 & $1989 / 01$ & $1995 / 11$ & 83 & $1989 / 01$ & $1995 / 11$ \\
\hline SPI-48 & -142.4 & $1987 / 05$ & $1996 / 11$ & 115 & $1987 / 05$ & $1996 / 11$ \\
\hline
\end{tabular}

Tablo 5'de SPI değerlerinin Mann-Kendall testi ile elde edilen eğilim sonuçları görülmektedir. Şekil 11'de yer alan grafiklerde ise SPI değerlerinin Mann-Kendall testi sonucu elde edilen $u(t)$ ve $u$ '(t) değerlerinin değişimi görülmektedir. Bu sonuçlara göre, tüm SPI dönemlerinde eğilimin, \%95 güven aralığında olmasa bile azalma (negatif) yönünde olduğu görülmektedir. Diğer bir deyişle, eğilim kuraklık yönünde olarak bulunmuştur. SPI-36 ve SPI-48 dönemlerinde istatistiksel olarak anlamlı olmaya yakın büyük bir azalma eğilimi olduğu söylenebilir.

Tablo 5: SPI değerlerinin eğilim sonuçları

\begin{tabular}{|c|c|c|c|c|}
\hline $\begin{array}{c}\text { SPI } \\
\text { aralı̆̆ }\end{array}$ & Ĕğilim & & $\begin{array}{c}\text { SPI } \\
\text { aralı̆̆ }\end{array}$ & Ĕğilim \\
\hline SPI-3 & -1.25 & SPI-24 & -1.33 \\
\hline SPI-6 & -0.91 & SPI-36 & -1.8 \\
\hline SPI-12 & -0.48 & SPI-48 & -1.8 \\
\hline
\end{tabular}




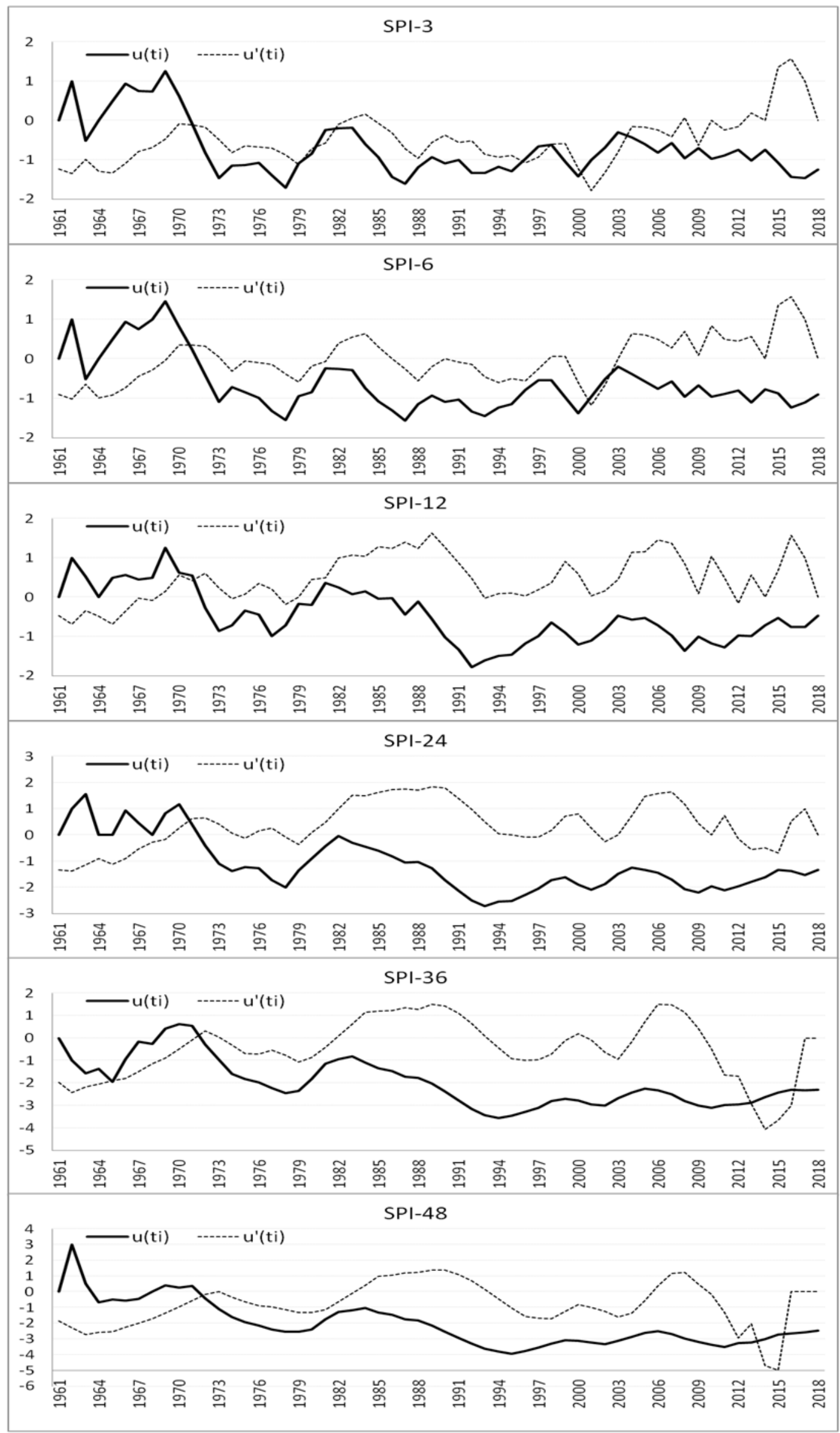

Şekil 11: Muğla ilinde 1-, 3-, 6-, 9-, 12-, 24- ve 36-aylık SPI değerlerinin Mann-Kendall test grafiği 
SPI indeksine göre 6 ay ve 2 aydan daha uzun süren kurak dönemlerin sıklığ Şekil 12’de görülmektedir. 2 aydan daha uzun süren kurak dönem, en sık olarak 3 aylık SPI periyodunda gerçeklemiştir. Bunu 6 aylık SPI periyodu takip etmiştir. 6 aydan daha uzun süren kuraklıklarda ise kurak geçen dönemlerin 6 aylık SPI periyodunda, diğer SPI periyotlarına göre daha fazla gerçekleştiği görülmektedir. Analizler, zaman periyodu arttıkça kuraklığın daha az tekrar ettiği ama daha uzun süreli etkili olduğunu göstermektedir. 3 aylık SPI zaman periyodunda kuraklık daha sık ama daha kısa süreli etkili olmakta, fakat zaman periyodu arttıkça (özellikle 12 ay zaman periyodunda) kuraklığın etki süresi artmakta, oluşum sıklığı azalmaktadır.

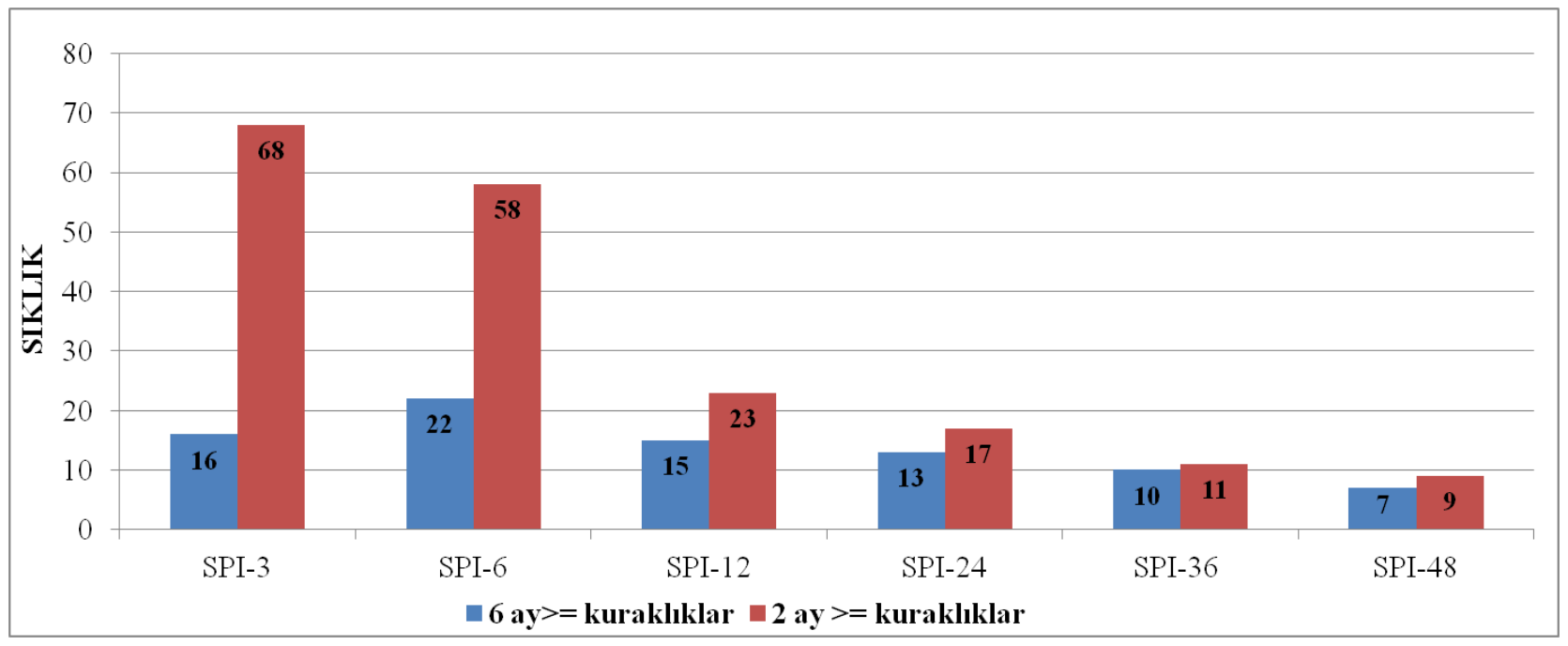

Şekil 12: SPI indeksine göre 6 ay ve 2 aydan daha uzun süren kurak dönemlerin sıklığı

\section{Değerlendirmeler}

Bu çalışmada, Muğla ilinin yağış durumu ile kuraklık durumu, yüzdesi, şiddet ve sıklığı analiz edilmiştir. Meteoroloji Genel Müdürlüğü Muğla Meteoroloji İstasyonu'na ait 1960-2018 dönemi yağış verileri kullanılmıştır. Verilerin homojenlik analizi için Run testi, kuraklık analizi için SPI yöntemi, trend analizi için ise Mann-Kendall testi kullanılmıştır. Sonuç olarak, Muğla ili için yıllık toplam yağışların 1960-2018 dönemi ortalaması 1180.2 mm olarak bulunmuştur. Çalışma döneminde en düşük yağış miktarı 2008 yılında 564.6 mm, en yüksek yağış miktarı ise 1969 yılında 1805 mm olarak gerçekleşmiştir. Muğla ilinde bazı dönemlerin kurak, bazı dönemlerin ise nemli geçtiği görülmüştür. Diğer bir deyişle, bölgede kuraklık durumunun seyrinde bir düzensizliğin olduğu görülmüştür. Bunu yanında, hafif nemli ve hafif kurak geçen ay sayılarının diğer sınıflara göre daha fazla olduğu görülmüștür. Ayrıca, ekstrem kurak dönem, ekstrem nemli döneme göre daha fazla gerçekleșmiștir. Muğla ilinde nemli ve kurak geçen ay sayılarının, çoğunlukla hafif ve orta şiddetlerde olduğu görülmüştür. Ancak yine de, şiddetli ve ekstrem kuraklık görülme riski her zaman bulunmaktadir.

Meteorolojik olarak ekstrem kurak dönemlerin 1964, 1965, 1968, 1969, 1970, 1973, 1981, 1984, 1989, 1990, 1992, 1999, 2004, 2007, 2008, 2012 ve 2016 yıllarında gerçekleștiği, ekstrem nemli dönemlerin ise 1975, 1998, 2002 , 2015 ve 2018 yıllarında gerçekleştiği görülmüştür. Tarımsal kuraklığın gerçekleştiği dönemler de meteorolojik kuraklığa benzer şekilde bulunmuştur. Hidrolojik olarak ise ekstrem kurak dönemlerin 1990, 1992, 2000, 2001, 2007 ve 2008 yıllarında gerçekleștiği, ekstrem nemli dönemlerin ise 1966, 1969 ve 2004 yıllarında gerçekleștiği görülmüştür. En ekstrem kurak dönemler 3-, 6-, 12-, 24-, 36- ve 48- aylık SPI dönemlerinde sirasıyla 2016 Aralık, 1984 Ekim, 2008 Aralık, 2008 Ekim, 1992 Aralık ve yine 1992 Aralık’ta görülmüştür. Bununla birlikte çalışma sonuçları, zaman periyodu arttıkça kuraklığın daha az tekrar ettiği ama daha uzun süreli etkili olduğunu göstermiştir. Muğla istasyonunun ölçekler bazında toplam kuraklık şiddeti ve toplam kuraklık süreleri hemen hemen benzer yıllara denk gelmiştir. Ancak, 3 aylık SPI periyodunda en güçlü toplam kuraklık şiddetinin (-13.90 değeri ile) 2006 Aralık - 2007 Eylül arasında görülmesine karşılık, etki süresinin daha düşük olduğu görülmüştür. Buna karşılık yaşanan en uzun süren kuraklık (12 ay), 2000 Haziran - 2001 Mayıs arasında görülmüştür.

Özetle, elde edilen sonuçlar, bölgede kuraklık durumunda bir düzensizliğin olduğunu ve \%95 güven aralığında olmasa bile eğilimin kuraklık yönünde olduğunu işaret etmektedir. Küresel iklim değişikliğinin bir sonucu olarak kuraklık olaylarının sıklığı ve düzensizliği fazla olmaktadır. Temelde küresel iklim değişikliği, kuraklıkla ilişkili faktörleri etkilemektedir. Sıcaklığın artması; beraberinde buharlaşma ve terlemenin artmasına, yağışlarda düzensizliğe, karın erken erimesine, dolayısıyla hidrolojik ve tarımsal kuraklık riskinin artmasına sebep olmaktadır. Gelecek çalışmalarda, küresel iklim değişikliğinin kuraklık üzerindeki etkisini daha iyi görebilmek maksadıyla, kuraklık trendinin Mann Kendall testi ile birlikte diğer yenilikçi yöntemler de göz önüne alınarak daha detaylı incelenmesi faydalı olacaktır. 
Bunun yanında, kuraklık analizleri özellikle tarım sektörü ve su kaynaklarının planlanması için de önemlidir. Yaşanan kuraklıklar beraberinde gıda ve su kıtlığını getirebilmektedir. Bu nedenle kuraklık kapsamında yapılacak analizler, alınacak önlemlerin de temelini oluşturmaktadır. Bu kapsamda gerçekleştirilecek analiz sonuçları baz alınarak, özellikle şiddetli ve uzun süren kuraklık olaylarının gerçekleştiği dönemi takip eden yıllar için su kaynakları ve gıdanın verimli kullanılması ve tasarrufu konularında planlamalar yapılması faydalı olacaktır.

\section{Kaynaklar}

Almedeij J., (2014), Drought Analysis for Kuwait Using Standardized Precipitation Index, The Scientific World Journal, 1(9), 1-10. Arslan O., (2017), Investigation of Trends in Meteorological Droughts in Niğde Province, Anadolu Univ. J. of Sci. and Technology A - Appl. Sci. and Eng., 8(5), 919-928.

Caloiero T., Veltri S., Caloiero P., Frustaci F., (2018), Drought Analysis in Europe and in the Mediterranean Basin Using the Standardized Precipitation Index, Water, 10(8), 1-13.

Chrysoulakis N., Proedrou M., Cartalis C., (2002), Variation and Trends in Annual and Seasonal Means of Precipitable Water in Greece as Decuded from Radiosonde Measurements, Toxicological and Enviromental Chemistry, 84(1-4), 1-6.

Çelik M.A., Kopar İ., Bayram H., (2018), Doğu Anadolu Bölgesi’nin Mevsimlik Kuraklık Analizi, Atatürk Üniversitesi Sosyal Bilimler Enstitüsü Dergisi, 22(3), 1741-1761.

Das V., Choudhury M.R., Gandhi S., Joshi V., (2016), Application of Earth Observation Data and Standardized Precipitation Index Based Approach for Meteorological Drought Monitoring, Assessment and Prediction Over Kutch, Gujarat, India, International Journal of Environment and Geoinformatics, 3(2), 24-37.

Dikici M., (2019), Asi Havzası'nda (Türkiye) Kuraklık Analizi, Doğal Afetler ve Çevre Dergisi, 5(1), 22-40.

Dinç N., Aydınşakir K., Işık M., Büyüktaş D., (2016), Standartlaştırılmış yağış indeksi (SPI) yöntemi ile Antalya ili kuraklık analizi, Derim, 33(2), 279-298.

Efstathiou M.N., Varotsos C.A., (2012), Intrinsic properties of Sahel precipitation anomalies and rainfall, Theoretical and Applied Climatology, 109(3-4), 627-633.

Estrela T., Vargas E., (2010), Drought management plans in the European Union, Water Resour. Manag., 26, 1537-1553.

Guttman N.B., (1999), Accepting the standardized precipitation index: a calculation algorithm, Journal of the American Water Resources Association, 35(2), 311-322.

Gürler Ç., (2017), Beyşehir ve Konya-Çumra-Karapınar Alt Havzalarında Standartlaştırılmış İndis Yaklaşımı İle Hidrolojik Kuraklık Değerlendirmesi, Uzmanlık Tezi, Su Yönetimi Genel Müdürlüğü, T.C. Orman ve Su İşleri Bakanlığı, Ankara.

Hınıs M.A., (2013), Bütünleşik Kuraklık İndeksi ile Aksarayda Hidrometeorolojik Kuraklık Analizi, Gazi Üniversitesi MühendislikMimarlık Fakültesi Dergisi, 28(4), 711-721.

IPCC, (2014), Summary for Policymakers: Fifth Assessment Report of the Intergovernmental Panel on Climate Change, Cambridge University Press, Cambridge, UK.

Kapluhan E., (2013), Türkiye'de kuraklık ve kuraklı̆̆ın tarıma etkisi, Marmara Coğrafya Dergisi, 27, 487-510.

Kreibich H., Baldassarre G. D., Vorogushyn S., Aerts J.C.J.H., Apel H., Aronica G.T., Arnbjerg-Nielsen K., Bouwer L.M., Bubeck P., Caloiero T., (2017), Adaptation to flood risk: Results of international paired flood event studies, Earth's Future, 5, 953-965.

Macana E., (2014), Büyük Menderes Havzasında Ortalama, Maksimum ve Minimum Sicaklıklarda 1970 Sonrasinda Gözlenen Ĕgilimler, Yüksek Lisans Tezi, Adnan Menderes Üniversitesi, Fen Bilimleri Enstitüsü, Tarımsal Yapılar ve Sulama Anabilim Dalı, Aydin.

Manatsa D., Mukwada G., Siziba E., Chinyanganya T., (2010), Analysis of multidimensional aspects of agricultural droughts in Zimbabwe using the Standardized Precipitation Index (SPI), Theoretical and Applied Climatology, 102(3), 287-305.

McKee T.B., Doesken N.J., Kleist J., (1993), The relationship of drought frequency and duration to time scales, 8th Conference on Applied Climatology, 17-22 January, American Meteorological Society, Boston, Mass, USA.

McKee T.B., Doesken N.J., Kleist J., (1995), Drought monitoring with multiple time scales, 9th AMS Conference on Applied Climatology, American Meteorological Society, Boston, Mass, USA, ss.233-236.

Oliver R.L, (1981), Measurement and Evaluation of Satisfaction Processes in Retail Settings, Journal Retailing, 57(3), 25-48.

Özsalmanlı A., (2014), Muğla Kenti ve Muğla Büyükşsehir Belediyesi Yönetimi, Adnan Menderes Üniversitesi Sosyal Bilimler Enstitüsü Dergisi, 1(5), 136-159.

Pamuk G., Özgürel M., Topçuoğlu K., (2004), Standart Yă̆ı̧ İndisi (SPI) ile Ege Bölgesinde Kuraklık Analizi, Ege Üniv. Ziraat Fak. Derg., 41(1), 99-106.

Sneyers R., (1990), On the statisitical analysis of series of observations, WMO Technical Note 143, Genova, 192ss.

Spinoni J., Naumann G., Carrao H., Barbosa P., Vogt J., 2(014), World drought frequency, duration, and severity for 1951-2010, International Journal of Climatology, 34(8), 2792-2804.

Topçu E., Seçkin N., (2016), Drought Analysis of the Seyhan Basin by Using Standardized Precipitation Index (SPI) and L-moments, Journal of Agricultural Sciences, 22(2), 196-215.

Toros H., (1993), Klimatolojik Serilerden Türkiye İkliminde Trend Analizi, Yüksek Lisans Tezi, İstanbul Teknik Üniversitesi, Fen Bilimleri Enstitüsü, İstanbul.

Türkeş M., Altan G., 2013, Muğla Yöresi’nde Gözlenen Kuraklıkların ve Nemli Koşulların Doğal Çevreye Etkileri ve İklim Değişikliği Açısından Analizi, 3. Uluslararası Coğrafya Sempozyumu, 10-13 Haziran, Antalya, ss.608-618.

URL-1, (2008), Muğla Coğrafi Yapısı, http://www.mecev.org.tr/incele.php?id=NjU=, [Erişi̇ 10 Şubat 2020].

Yerdelen C., (2013), Susurluk havzası yıllık akımlarının trend analizi ve değişim noktasının araştırılması, Dokuz Eylül Üniversitesi Mühendislik Fakültesi Mühendislik Bilimleri Dergisi, 15(2), 77-87.

Yetmen H., (2013), Van Gölü Havzası'nın Kuraklık Analizi, 21. Yüzyılda Eğitim ve Toplum, 3(5), 184-198.

Yevjevich V.M., (1967), An objective approach to definitions and investigations of continental hydrologic droughts, Hydrology Papers, No. 23, Colorado State University, Fort Collins. 